University of Rhode Island

DigitalCommons@URI

Senior Honors Projects

Honors Program at the University of Rhode

Island

$5-2015$

\title{
Effect of an Exercise and Dietary Intervention on Cognitive Function in Obese Older Women
}

Kathleen Mae Uy

University of Rhode Island, kathleenmuy@gmail.com

Follow this and additional works at: https://digitalcommons.uri.edu/srhonorsprog

Part of the Exercise Science Commons

\section{Recommended Citation}

Uy, Kathleen Mae, "Effect of an Exercise and Dietary Intervention on Cognitive Function in Obese Older Women" (2015). Senior Honors Projects. Paper 388.

https://digitalcommons.uri.edu/srhonorsprog/388

This Article is brought to you for free and open access by the Honors Program at the University of Rhode Island at DigitalCommons@URI. It has been accepted for inclusion in Senior Honors Projects by an authorized administrator of DigitalCommons@URI. For more information, please contact digitalcommons-group@uri.edu. 
THE

UNIVERSITY

OF RHODE ISLAND

Effect of an exercise and dietary intervention on the

\section{cognitive function on obese older women}

K Uy ${ }^{1}$ S Maris ${ }^{2}$, D Quintanilla², A Taetzsch², A Picard ${ }^{3}$, J Letendre ${ }^{2}$, F Xu ${ }^{1}$, IE Lofgren ${ }^{2}$, L Mahler $^{1}$, MJ Delmonico ${ }^{1}$

'Department of Kinesiology, ${ }^{2}$ Department of Nutrition and Food Sciences, ${ }^{2}$ Department of Communicative Disorders University of Rhode Island, Kingston, RI 0288

\section{Introduction}

Risk of cognitive decline and disease are higher in minorities [1]

Physical activity and healthy dietary patterns have been linked to the prevention of

ognitive decline in older adults $[2,3]$

政

ported [4]

Therescises positively effect cognitive and memory function [5].

een similar studies on cognitive function but there are no significant data on the effect of Tai Chi, resistance training, and a dietary intervention on

cognitive functior

\section{Purpose}

The Purpose of this study was to examine the effect of a combined Tai Chi, resistance training and dietary intervention on cognitive function in older obese women.

\section{Hypothesis}

tis hypothesized that a combined Tai Chi, resistance training and dietary intervention will show positive effects on cognitive function in older obese women.

\section{Study Design}

A non-randomized experimental design with baseline testing prior to the intervention and post-testing at the conclusion of the 12-week intervention. The study took place at St. Martin de Porres Senior Center in Providence, Rhode Island.

Study approved by the Institutional Review Board of the University of Rhode Island \#HU1213-08)

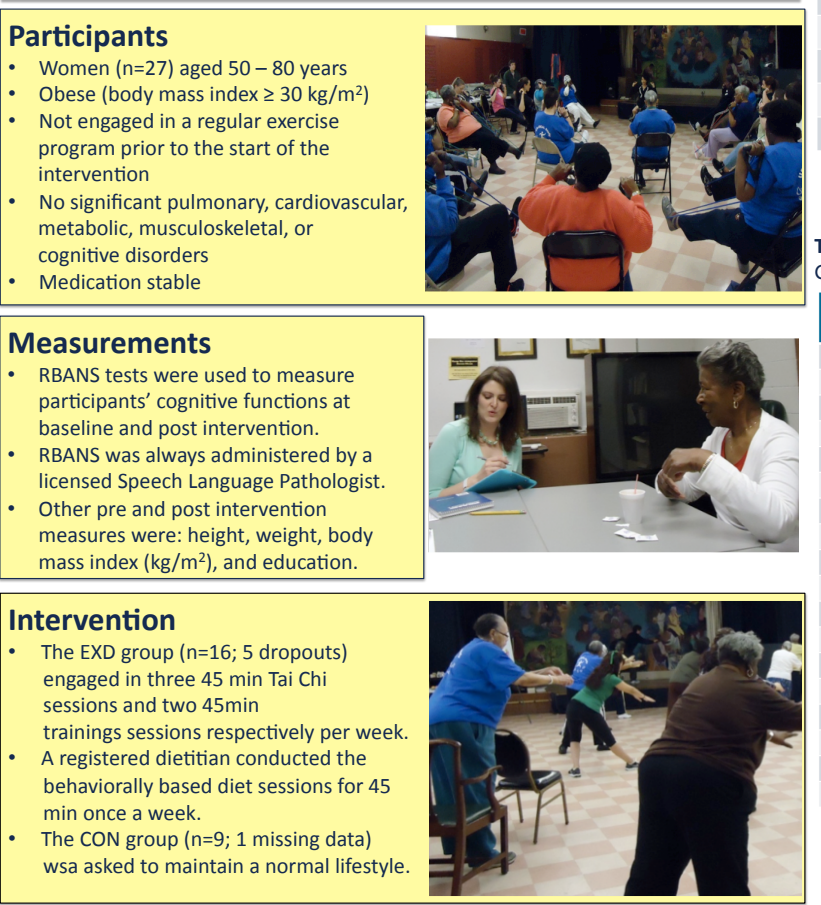

Statistical Analysis

Statistical analysis was performed using SAS statistical software. Significance was set at $p<0.05$

Normality was assessed using Shapiro-Wilk test.

No outliers were identified using the 3 standard deviations above or below the mean.

- Fisher's Exact tests were used to analyzed education level and race/

ethnicity.

-group baseline values.

- Paired t-test for within group values.

To compare between group data, analysis of covariance using the changed score adjusted for baseline values.

Results

Table 1: Baseline Characteristics of the Intervention (EXD) and Control (CON) Groups

\begin{tabular}{|c|c|c|c|}
\hline Characteristics: & $\begin{array}{c}\text { EXD Group } \\
(\mathrm{n}=16)\end{array}$ & $\begin{array}{c}\text { CON Group } \\
(\mathrm{n}=9)\end{array}$ & p-value \\
\hline $\mathrm{Age}^{1}$ & $66.0(7.6)$ & $66.2(8.0)$ & 0.945 \\
\hline
\end{tabular}

High School or Less (n)

Associates or Some College

Bachelors or Higher ( $n$

Weight $(\mathrm{kg})^{1}$

Height $(\mathrm{cm})^{1}$

Body Mass Index $\left(\mathrm{kg} / \mathrm{m}^{2}\right)$

Race/Ethnicity ${ }^{2}$

Non-White $(n)$

White ( $n$ )

Continuous data are expressed as mean (standard deviation.

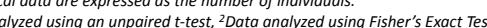

Table 2: Changes in RBANS Scores between Intervention (EXD) and Control (CON) roups Post Intervention.

\begin{tabular}{|c|c|c|c|}
\hline RBANS Categories & $\begin{array}{c}\text { EXD Group } \\
(\mathrm{n}=16)\end{array}$ & $\begin{array}{c}\text { CON Group } \\
(\mathrm{n}=9)\end{array}$ & p-value \\
\hline RBANS Overall Score & $3.1(2.0)$ & $2.1(2.7)$ & 0.995 \\
\hline Immediate Memory & $4.1(2.8)$ & $12.7(3.7)$ & 0.078 \\
\hline List Learning & $2.0(0.8)$ & $3.0(1.1)$ & 0.475 \\
\hline Story Memory & $1.8(0.7)$ & $3.3(0.9)$ & 0.204 \\
\hline Visuospatial/Constructional & $8.9(3.5)$ & $-3.9(4.6)$ & 0.038 \\
\hline Figure Copy & $1.1(0.5)$ & $-0.4(0.6)$ & 0.081 \\
\hline Line Orientation & $2.1(0.1)$ & $-0.1(1.1)$ & 0.147 \\
\hline Language & $-0.7(3.3)$ & $-0.2(4.4)$ & 0.918 \\
\hline Picture Naming & $-0.2(0.3)$ & $0.1(0.4)$ & 0.507 \\
\hline Semantic Fluency & $0.9(1.4)$ & $-1.2(1.9)$ & 0.394 \\
\hline Attention & $-4.0(2.1)$ & $3.5(2.9)$ & 0.047 \\
\hline Digit Span & $-0.9(0.6)$ & $-0.9(0.9)$ & 0.934 \\
\hline Coding & $0.6(1.5)$ & $-0.2(2.0)$ & 0.754 \\
\hline Delayed Memory & $4.6(2.7)$ & $4.2(3.6)$ & 0.944 \\
\hline List Recall & $0.5(0.4)$ & $-0.2(0.5)$ & 0.270 \\
\hline List Recognition & $0.5(0.2)$ & $0.5(0.3)$ & 0.968 \\
\hline Story Recall & $2.0(0.5)$ & $0.8(0.6)$ & 0.117 \\
\hline Figure Recall & $2.0(0.8)$ & $-0.4(1.0)$ & 0.074 \\
\hline
\end{tabular}

Figure 1: Total RBANS Average Score Change $\quad$ Figure 2: RBANS Subcategory Changes Between EXD and CON Groups $6 \longdiv { B } 3$ Between EXD and CON Groups

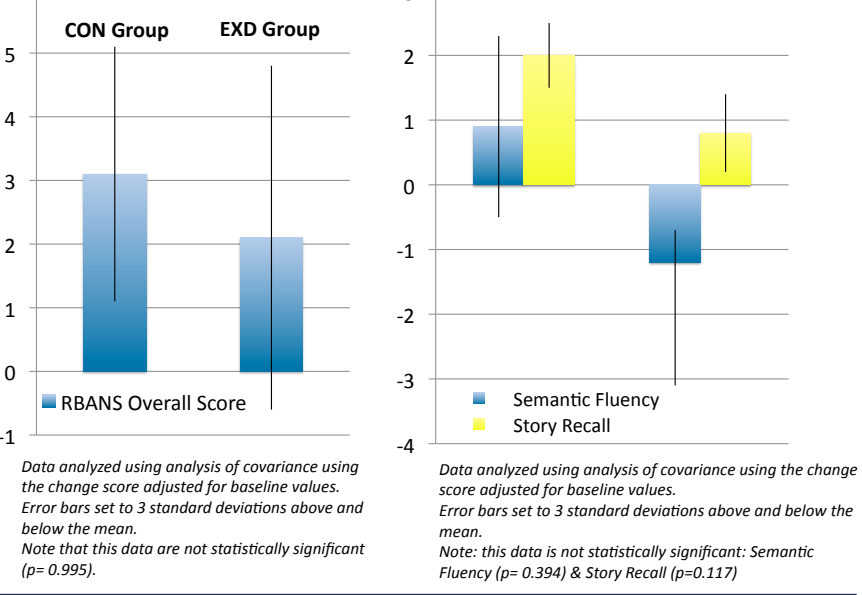

Discussion and Conclusion

- There were no significant RBANS score changes between the EXD and CON Groups. Results show positive and negative results in different RBANS categories and subcategories.

- Strengths of the study were the target population, which include a strong minority population, the combined interventions effects and the presence of a CON group This is the first study to report the combined cognitive effects of a 12-week Tai Chi - Limitations of this study were the non randomized design, small sample size, and the study's main focus was on the anthropometric and blood pressure changes. - The RBAns subcategory "Stony Recall a and "Sema Parkinson's disease [8].
Pecause been shown to be lower in individuals with

\section{References}

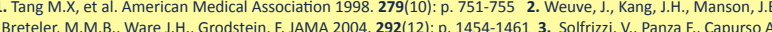
Journal of Neural Transmission 2003 110: p. 95-110 4. Naderali, E.K., et. al. American Journal of

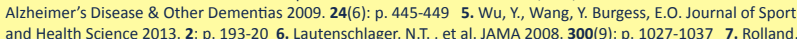

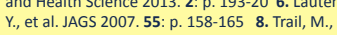

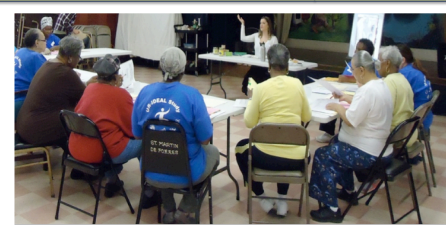
ersonal Purpose for the Honors Proje was involved fully involved with the 作 from the beginning to end and 1 weate a formal poster presentation. My goal was to achieve a full understanding of the Acknowledgements Agriculture, under Project NO. RIO0NE-1039-INT Communicative Disorders for their handwork and efforts during this study. , CCC-SLP for their support and entorship throughout the project 